\title{
EDUCATIONAL PORTAL SEEN AS A KEY COMPONENT OF INFORMATISATION OF CONTEMPORARY TERTIARY EDUCATION
}

\author{
Valentyna Bobrytska \\ ORCID iD 0000-0002-1742-0103 \\ Doctor of Education, Professor \\ Professor of the Department of Social Philosophy, \\ Philosophy of Education and Educational Policy \\ for the National Pedagogical University \\ named after M. P. Dragomanov \\ 9 Pirogova Str., 01601 Kiev, Ukraine \\ bobrytska@ukr.net
}

\section{ABSTRACT}

The article reveals the role of an education portal as a key component of informatisation of modern tertiary education; proves the applicability of using of Web-pages of the educational portal in occupational activity of teachers/lecturers in the settings of informatisation of tertiary school; specifies the structural components of the educational Portal along with the main features of an educational portal of higher educational institution; gives the insights into the types of portals (horizontal, vertical) viewed as a key component of informatisation of tertiary school; highlights best practices of the use Web-portal pages in the process of professional training of students of higher educational institutions; reveals the advantages of the educational portal regarded to be the key component of informatisation of tertiary education; outlines the essential features of the basic concepts for this study.

Key words: educational space; portal; educational portal; informatisation of education; portal toolkit.

\section{PROBLEM STATEMENT}

Specific features of the development of modern civilization process mainstream new requirements for training the future professionals in the settings of educational process in higher educational establishments (HEE). Given this, informatisation of higher education is an important phenomenon of our contemporaneousness, one of the strategic directions of information society and one of the determinant characteristics of its incremental development. It is universally acknowledged that in conditions of transition of developed countries from the post-industrial to information society informatisation of education becomes a powerful resource of society and the state (Bobrytska, 2016). Accordingly, Ukraine's accession to the global educational and information space requires every teacher/lecture of higher school to be conscious of the great responsibility for the quality of both educational services provided, and training of future professionals who are supposed and intended to be professionally competent and competitive in the global labour market (Bobrytska, 2015; Bobrytska, 2016). 


\section{ANALYSIS OF RESEARCHES AND PUBLICATIONS}

The study of information sources affords ground for the conclusion that in Ukraine there is paid a due attention to the problems of informatisation of tertiary education in terms of the use ICT in the educational process of institutions. The aspects of significant current interest of the aforementioned problems are highlighted in the works of V. Bykov, V. Bobrytska, T. Kaliuzhna, N. Zadorozhnia, T. Omelchenko, A. Jafari, M. Sheehan, M. Cruz-Cunha, E. Peres, J. Polgar, G. Adamson, E. Santos, E. Boff, R. Vicari, U. Torres Maldonado, G. Feroz Khan, J. Moon, J. Jeung Rho and others. Still, the investigations of applicability of using educational portal as a key component of informatisation of modern higher education have been done fragmentarily, which proves the feasibility of this study.

\section{AIM OF THE ARTICLE}

This research purpose is to justify the feasibility of using an educational portal as a key component of informatisation of contemporary tertiary education.

For the above purpose, there were specified the following objectives: to reveal the role of the educational portal as a key component of Informatisation of modern higher education; to highlight practical aspects of using Web-portal pages in the professional training of HEE students.

\section{THE MAIN MATERIAL}

In our view, the relevance of informatisation of education is related to the fact that currently the academic success of students consistently correlates to the quality of their training concerning the use of information and communication technologies (ICT), their ICT competence. Specifically, at the stage of obtaining higher education, it is not the volume that determines the effectiveness of perception of educational information by students but their ability to be conversant in information flows, to be autonomous in acquiring new knowledge, to exercise self-control over the implementation of actions, to be able to continue their professional development in the settings of the knowledge society (Bobrytska, 2015, p. 273-274). Informatisation of education in higher education establishment is aimed at training a qualified professional of the appropriate qualification level and profile, who is competitive, competent, mobile, able to perform meeting international standards, ready for continuous professional development throughout the one's entire life. With the development of information and communications spheres of society, modernisation process of tertiary education should be given urgent requests for its quality, improving efficiency, intensity and instrumentality, reduction the complexity of the use of information resources in the educational process of HEE. Given this, we believe that in the settings of development of information and communications spheres of society, modernisation process of education should be performed taking into consideration its quality, efficiency improvements, intensity and instrumentality, reduction the complexity of the use of information resources in the educational process of HEE (Bobrytska, 2011; Bobrytska, 2015).

In their study we are to refer to the definition that is offered in the «Encyclopedia of Education» and is, in our view, a comprehensive one: 
«Informatisation of education is an ordered set of interrelated organisational, legal, social and economic, scientific and methodological, scientific and technical, production and management processes intended to meet the information, computational and telecommunication problems related to the capabilities of methods and means of information and communication technologies and participants of the educational process, along with those who manage and maintains this process» (Encyclopedia of Education, 2008).

First, we note that in the majority of scientific and pedagogical sources the phenomenon of educational space is revealed as a certain instructional unit, which involves close contact a person with the surrounding educational environment. As a result of this interaction, there occurs perception and experience of all elements-carriers of culture. From this perspective, it is possible to call the above space a structured educational system of instructional factors and conditions of familiarisation with it by an individual in the process of professional development and job placement.

Therefore, a key tool for the creation of educational space in the modern university is supposed to be the use of education portal. It is noteworthy that in the information circulation, there are other approaches to interpretation the term «portal»: informational one and functional one. When using information approach, it is a single access point to information resources of the enterprise, while applying a functional one, it is a container for technological services, which combines search function, newsletters mailing, possible cooperatively performed projects and others (Bykov, Zadorozhnia, Omelchenko, 2004). We note that in this study we will consider «educational portal» as a site, which is organized as a system multi-level integration of the various resources and services.

There are horizontal portals, portals of general purpose (offering a set of services and focus on different topics) and vertical portals (focus on a particular theme and provide various services within it).

In their study, we will give the insight into a horizontal portal considering it to be a professionalism-related portal involving academic majors like: humanitarian, economic and social, natural sciences, engineering, teaching, medicine, agriculture, etc. (Fig. 1).

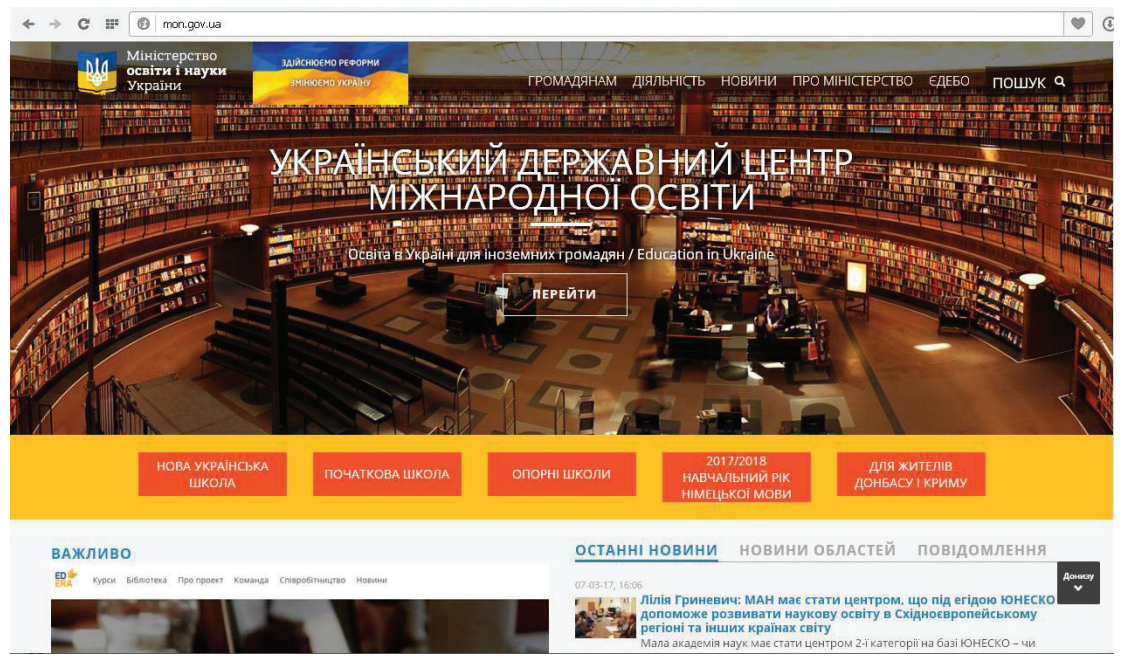

Fig. 1. The example of a horizontal portal.

Information resource. URL: http:// mon.gov.ua (In Ukrainian). 
It should be mentioned that we associate the vertical portal with the site related to a particular sphere or certain problem (fig. 2). The notion «portal toolkit» is interpreted by the domestic researchers as a means to facilitate the tasks of the teacher associated with the coordination and management of the course materials using/student's access to those materials; possibilities exercised by a student in his/her place of residence as a participant of distance learning course; possibility to facilitate the design and launch of training activities limited to less than a whole course, for example, tasks, assignments, modules, conversational topics, etc.
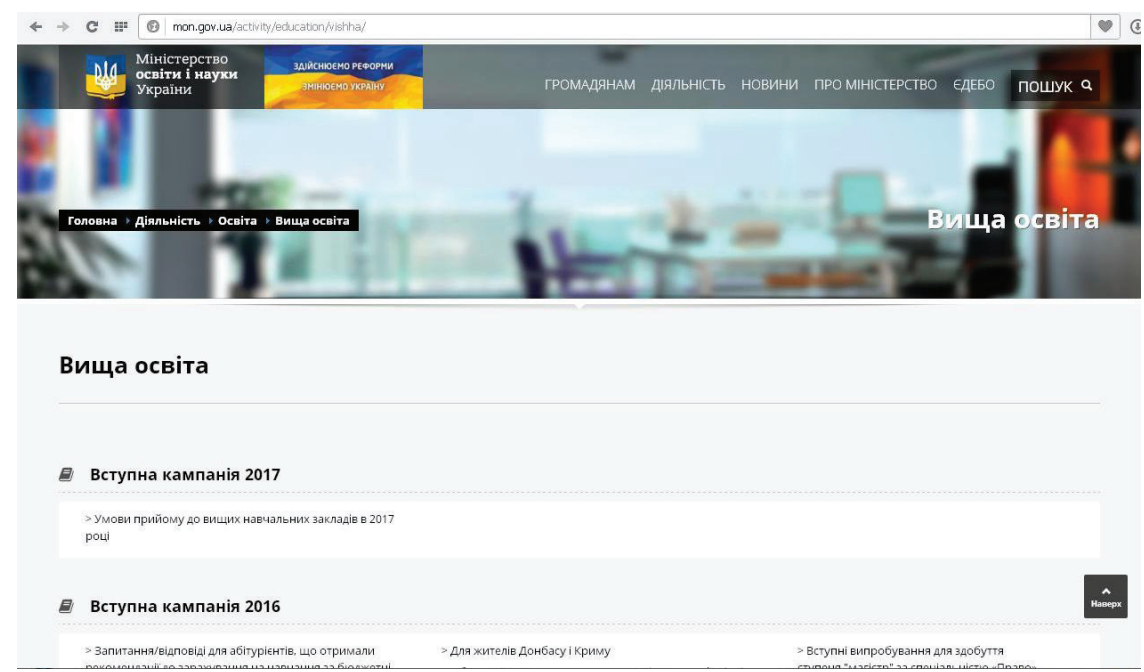

Fig. 2. The example of a vertical portal.

Information resource. -

URL: http:// mon.gov.ua/activity/education/vishha/ (In Ukrainian).

Under the means of the educational portal, we mean the functional elements (toolkit) of the structure of the portal. The structure of the portal includes the following components: 1) presentation section (portal menu, participants and staff, news block, services, events etc.); 2) information section (primary, informative, analytical information); 3) administrative section (registration and authentication, access restrictions, information search on the portal, means of export/import data, testing).

The portal has a centralized 'Sign-in' and 'Log-in' options, and special tools for surfing information resources easily.

From this perspective, the use of the portal enables: 1) promptly post the information resources on the web; 2) to engage many organisations into development of the content; 3 ) to expedite access to information on the portal topic any time, whatever location of the user is, whatever region the one is from, and whatever the one's interests are; 4) to raise information awareness of the decisionmakers; 5) to reach the potential users through the information on the subject of their interest; 6) to raise additional financial resources through more active use of information resources by a wider range of users.

Educational portals, being a software and hardware complex, which accumulates in various forms and amounts of geographically distributed data on scientific and methodological information resources, modern technologies of education, state educational standards and any other information that supports 
education and individual interest in continuing to improve it, play an important role in modern educational process of HEEs.

Thus, the problem of creation and development of educational portals has still been relevant in the educational process of modern HEE.

Currently being used educational portals are a software and hardware complex, which accumulates, in various forms and amounts of geographically distributed, data on scientific and methodological information resources, modern instructional technologies, state educational standards and any other information that maintains the personal level of education and interest in continuing improving it (Kaliuzhna, 2009).

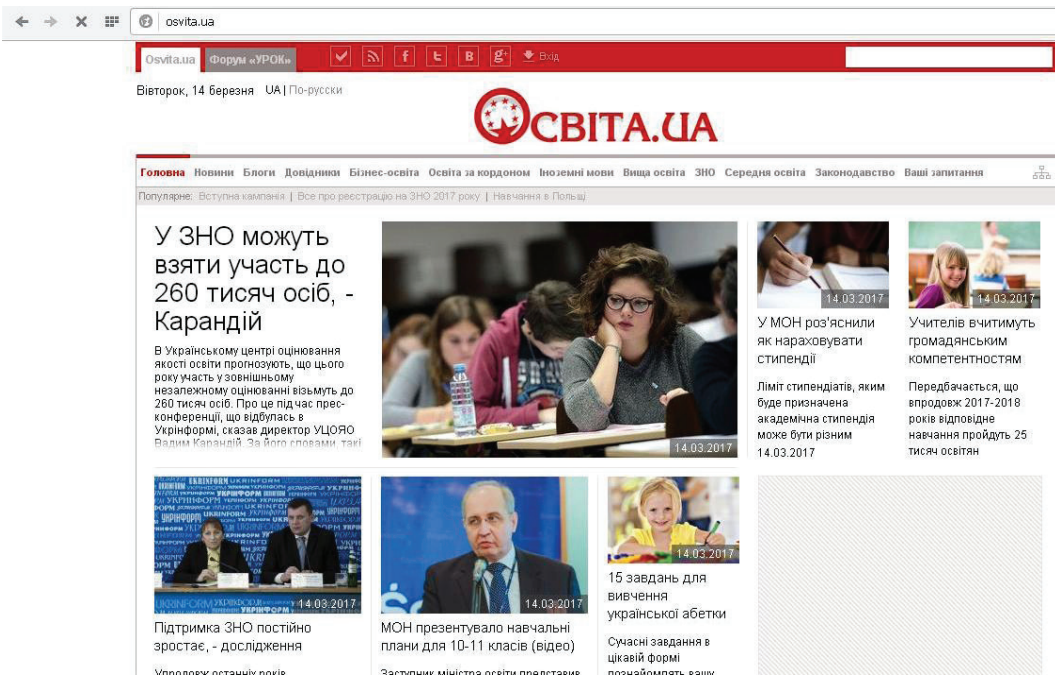

Fig. 3. The example of educational portal.

Information resource. - URL: http:// osvita.ua (In Ukrainian).

We are convinced that when running the educational portal, every student is provided with an opportunity to communicate with the teacher. Such communication process does not only improve the efficiency study of the academic discipline, but also teaches students to self-obtain further knowledge which is the key to their successful professional activity.

After completing the scientific research, we will define basic features of the education portal of a modern HEE (Bykov, Zadorozhnia, Omelchenko, 2004; Bobrytska, 2015): the existence of a developed system of information resources with operating interaction with users through forums and with the option available to integrate and aggregate large volumes of different types of data; availability of flexible search mechanisms; availability of service: availability of the portal content personalisation for a certain service user and portals services which are typical for all types portals; specialised services providing opportunities for the adequate access to various electronic educational resources, such as: libraries; distance courses; testing systems; the system of remote access to the centres of collective use of educational computing and experiments-related resources; the latest means of access to the content of individual and corporate users.

At the National Pedagogical University named after M. P. Dragomanov there has accumulated some experience of practical application of the educational portal in the training of future employees of the educational sector (fig. 4). 


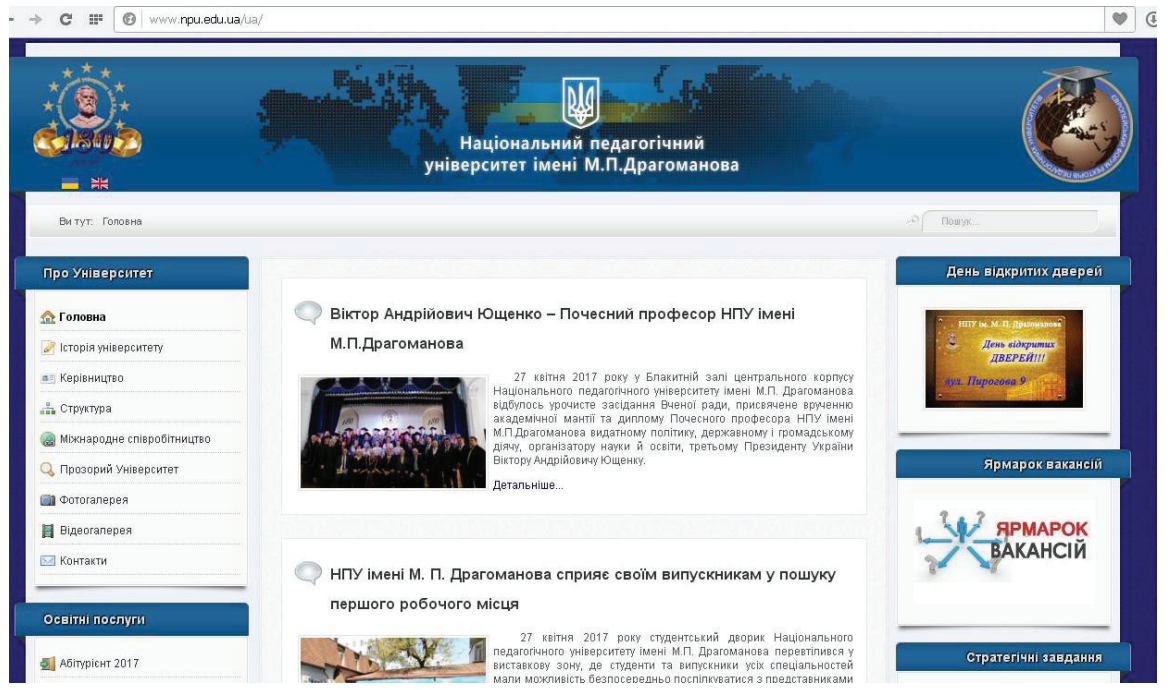

Fig. 4. The example of the educational portal of the National Pedagogical University named after M. P. Dragomanov.

Information resource. - URL: http:// www.npu.edu.ua/ua/ (In Ukrainian).

Specifically, lecturers for the Department of Social Philosophy and Philosophy of Education and Educational Policy developed personal web-pages on different educational portals, where teachers/lecturers are encouraged to places their scientific and official materials (information unit) (fig. 5).

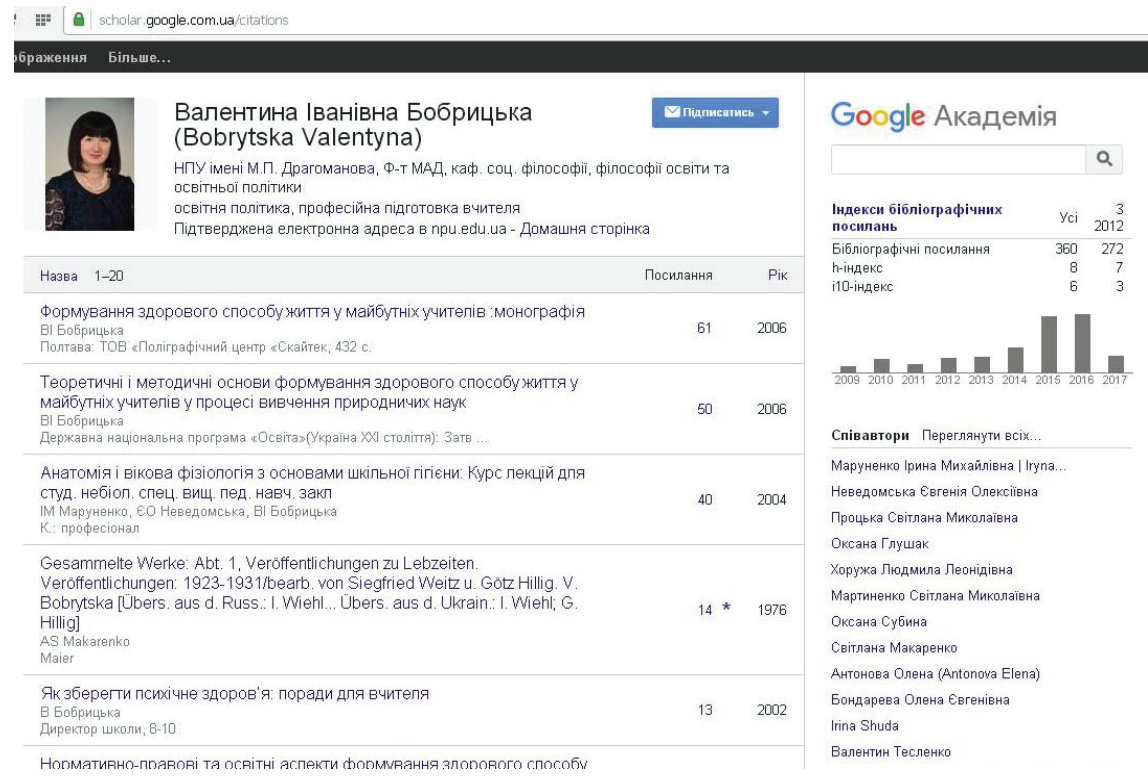

Fig. 5. The examples of personal research and official reports to have been placed on educational portals.

Information resource. - URL: https://scholar.google.com.ua/ citations?user=KRC Ex5YAAAAJ\&hl=ru

The experience gained with the use of educational portal proved practicability of this activity due to the fact that the collaborative work with documents, 
discussions of the topics in blogs and forums provides opportunity to involve and motivate students to study.

Additionally, the teachers/lectures of HEEs will seize the opportunities to use educational portal as a site which is developed as a systemic multilevel integration of the various resources and services.

In particular, it has been proved its effectiveness the use of open, free and free electronic (online) resources - educational software, electronic course-books, language games, video and audio files that can be used in the education process of HEEs; independent creating of content - texts, presentations, sketches, drawings, photographs, video and audio materials; participation in new forms of educational and cognitive activity that is related to the search for foreign information, and creation one's own content; membership in professional-scholarly communities, which extends the range of educational/professional activities and cooperation with other students/professionals.

\section{CONCLUSIONS}

Concluding the above, we will justify the feasibility of using the educational portal in the modern HEE with regard to its advantages, namely:

- accessibility (access to the resource is possible from every student's computer having access to the Internet);

- openness (hypertext system of providing information enables the student, while obtaining the profession, to choose their own «path» of mastering educational information, given the dynamics of their own cognitive processes, their learning interests, abilities and skills to process information resources);

- visualisation of educational material (with the help of multimedia technology used in the WWW-services of the Internet, including educational portals, you can optionally embed in the body of the educational material elements of the test with illustrations, animations, videos, information voiced or to voice it, etc.);

- interactive-mode resource (interactive forms of information exchange which are posted on the portal Web-pages enable students to individually choose the options of search, selection, structuring and downloading educational information).

We believe that creation of the educational portal has a powerful potential for informatisation of the contemporary tertiary education, and it is an effective means of making it possible, as an educational portal contributes to the improvement of traditional teaching methods, to the use of innovative forms and methods of educational process in HEEs, to implementation of cultural and educational activities, to logical streamlining of educational materials, and, correspondingly, to improving the quality of educational services, to accelerating integration of Ukraine's education system into the world educational space.

The prospects for further scientific investigations are seen in the development of pedagogical conditions of monitoring results of using educational portal in the educational process of contemporary HEEs. 


\section{REFERENCES}

Bykov, V. Y., Zadorozhnia, N. T., \&Omelchenko, T. H. (2004). Suchasni pidkhody ta pryntsypy pobudovy portaliv. Zasoby i tekhnolohiyi yedynoho informatsiynoho osvitn'oho prostoru [Current Approaches and Principles of Development the Portals. Tools and Technologies of a Common Information Educational Space]: coll. scien. papers. V. Y. Bykova, Y. O. Zhuka (Eds.), Institute of Means of Education of APS, Kyiv, Ukraine: Atika, 17-44.

Bobrytska, V. I. (2011). Zastosuvannya informatsiyno-komunikatsiynykh tekhnolohiy u vyshchiy pedahohichniy osviti [The Use of ICT in Higher Pedagogical Education]. Pedagogical education: Theory and Practice. Pedagogy. Psychology, № 16 (2), 35-39.

Bobrytska, V. I. (2015). Osvitnya polityka Ukrayiny u sferi informatyzatsiyi osvity [Education Policy of Ukraine in the field of informatisation of education]. In V. P. Andrushchenko (Ed.), Educational Policy: Philosophy, Theory, Practice, 273-316.

Entsyklopediya osvity [Encyclopedia of Education]. (2008). V. Kremen (Ed.). Kyiv, Ukraine: Unicom Inter.

Kaliuzhna, T. M. (2009). Orhanizatsiyno-pedahohichni umovy zastosuvannya osvitn'o-naukovoho portalu v systemi eksternatnoyi pidhotovky fakhivtsiv $u$ tekhnichnomu universyteti [Organizational and pedagogical conditions of educational and scientific portal application to the system of external studies in technical university] (Candidate's thesis).

Bobrytska, V. (2016). Axiological Azimuths of the Global Educational Policy. Proceedings of the National Aviation University, 67, 3, 89-97. doi: 10.18372/2306-1472.68.10912.

Designing Portals: Opportunities and Challenges. (2003). Ali Jafari, Mark C. Sheehan (Eds.), IRM Press (am imprint of Idea Group Inc.), USA, 318. doi: 10.4018/978-1-59140-108-7.

International Journal of Web Portals (IJWP). Maria Manuela Cruz-Cunha, Emanuel Soares Peres (Eds.), 2009-2017, Semi-Annually, Portugal, 1-9. doi: 10.4018/IJWP.

New Generation of Portal Software and Engineering: Emerging Technologies. (2011). Jana Polgar, Greg Adamson (Eds.), IGI Global, Australia, 298. doi: 10.4018/978-1-60960-571-1.

Santos, E. R., Boff, E., \& Vicari, R. M. (2006). Semantic Web Technologies Applied to Interoperability on an Educational Portal. In: M. Ikeda, K. D. Ashley, T. W. Chan (Eds.), Intelligent Tutoring Systems. ITS 2006. Lecture Notes in Computer Science, vol 4053. Springer, Berlin, Heidelberg. doi: 10.1007/11774303_31.

Ursula Paola Torres Maldonado, Gohar Feroz Khan, Junghoon Moon, \& Jae Jeung Rho. (2011). Elearning motivation and educational portal acceptance in developing countries. Online Information Review, 35(1), 66-85. doi: 10.1108/14684521111113597. 